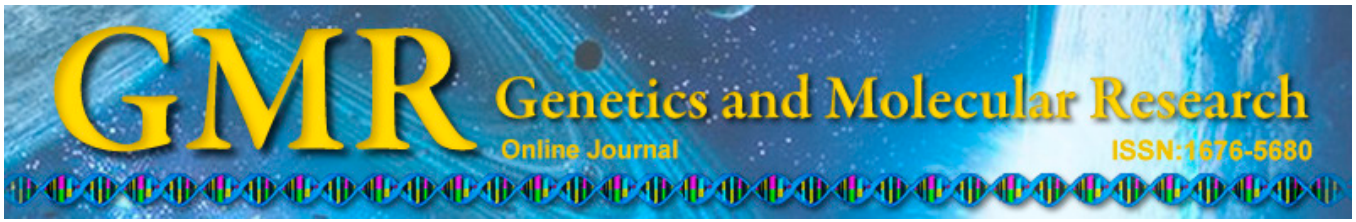

\title{
Physiological quality and gene expression during the development of habanero pepper (Capsicum chinense Jacquin) seeds
}

\author{
H.O. Santos, E.V.R. Von Pinho, I.V. Von Pinho, S.M.F. Dutra, \\ T. Andrade and R.M. Guimarães \\ Departamento de Agricultura, Universidade Federal de Lavras, \\ Lavras, MG, Brasil \\ Corresponding author: H.O. Santos \\ E-mail: heloisasantos@dag.ufla.br
}

Genet. Mol. Res. 14 (2): 5085-5098 (2015)

Received August 28, 2014

Accepted December 12, 2014

Published May 12, 2015

DOI http://dx.doi.org/10.4238/2015.May.12.11

\begin{abstract}
Phytohormones have different characteristics and functions, and they may be subject to changes in their gene expression and synthesis during seed development. In this study, we evaluated the physiological qualities of habanero peppers (Capsicum chinense Jacquin) during seed development and the expression of genes involved in germination. Seeds were obtained from fruits harvested at different stages of development [i.e., 14, 21, 28, 35, 42, 49, 56, 63, and 70 days after anthesis (DAA)]. Immediately after harvesting, the seeds were subjected to various tests to determine moisture content, germination, first count germination, and seedling emergence. Real-time polymerase chain reaction was used to evaluate the expression of various genes, including MAN2, NCED, B73, ICL6, and GA3ox. Electrophoresis was used to assess the expression of various enzymes, including $\alpha$-amylase, isocitrate-lyase, and endo- $\beta$-mannanase. Habanero peppers harvested at 70 DAA and subjected to 7 days of rest exhibited higher germination rates and vigor compared to those harvested at all other developmental stages. Peppers harvested at 63 DAA without drying exhibited higher $\alpha$
\end{abstract}


amylase and $A m y B 73$ gene expression levels. Peppers harvested at 70 DAA with 7 days of rest exhibited higher endo- $\beta$-mannanase expression levels. MAN2 gene expression increased during the development of non-dried seeds until 70 DAA. Peppers harvested at 42 DAA exhibited the highest isocitrate-lyase and ICL6 gene activity levels in comparison to those at all other developmental stages.

Key words: Germination; Real-time PCR; Seed quality; Seed vigor

\section{INTRODUCTION}

Recently harvested seeds from species belonging to the genus Capsicum are capable of entering a dormant stage (Bosland and Votava, 1999). Thus, under certain circumstances, a delay in germination and reduction in emergence have been linked to seed dormancy. However, dormancy may last for relatively short periods and can be overcome by seed storage.

However, even though reports of dormancy in pepper seeds exist, the successful establishment of plantlets in greenhouses was also documented when the seeds from specific cultivars were harvested and sown from completely ripened fruits (Bosland and Votava, 1999). Randle and Honna (1981) described the influence of genotype and fruit age on the intensity of seed dormancy in different cultivars from the genus Capsicum. The authors stated that seeds harvested from ripened fruits germinate more rapidly, with younger fruits displaying a higher intensity of seed dormancy.

Phytohormones affect the mechanisms involved in seed dormancy and germination. The expression levels of genes that control the biosynthesis of abscisic acid (ABA) could be associated with the dormant state. There is evidence that ABA is an important regulator of seed dormancy and germination, contributing to both the induction and maintenance of these states. In contrast, gibberellins are hormones that cause seeds to germinate. In certain species, these phytohormones are important in the synthesis of key enzymes involved in seed germination, such as endo- $\beta$-mannanase and $\alpha$-amylase (da Silva et al., 2004).

To develop technologies that guarantee the production and commercialization of highquality seeds, it is essential to improve our understanding of the expression of these genes. Thus, the current study aimed to evaluate the physiological quality of habanero pepper seeds during development and the expression of the genes involved in seed germination.

\section{MATERIAL AND METHODS}

This study was performed in the experimental area and Central Seed Laboratory of the Agriculture Department, Federal University of Lavras, Lavras, Minas Gerais, Brazil. A randomized block design, with 4 replications, was adopted to produce habanero pepper (Capsicum chinense) seeds. Each section was composed of 15-m long rows, with 15 plants in each row and $1.5-\mathrm{m}$ spacing between rows. The recommended cropping conditions were followed for the cultivation of these crops.

During the flowering stage, flowers were checked daily and labeled on the day of anthesis until a sufficient number of seeds were obtained to perform all of the required analyses. Fruits were harvested at 14, 21, 28, 35, 42, 49, 56, 63, and 70 days after anthesis (DAA). Following harvest, the seeds were manually removed and washed under running water. Analyses 
were also performed on fruits harvested at 70 DAA, followed by 7 days of rest. Hence, a total of 10 treatment groups were analyzed. Recently, harvested seeds were subjected to quality testing, which included germination, vigor, and moisture content. A portion of these seeds was stored in a freezer at $-84^{\circ} \mathrm{C}$ to analyze the expression of the enzymes and genes involved in seed germination. Another portion of the harvested seeds was subjected to slow drying in a forced air incubator at $35^{\circ} \mathrm{C}$ until an approximate moisture content of $8 \%$ was reached (Queiroz et al., 2011).

The methods used to assess the moisture content and germination of the seeds were performed in accordance with the Rules for Seed Testing (Brasil, 2009). First count of germination was assessed and the germination test was conducted at day 7 post-sowing by determining the percent of normal plantlets. The remaining seeds from the germination test were subjected to a tetrazolium test to assess viability. In addition to the germination test, a seedling emergence test was performed under controlled conditions, with 4 replications.

For the electrophoretic analysis of the enzymes $\alpha$-amylase, isocitrate-lyase, and endo$\beta$-mannanase, the seeds were first ground using a mortar and pestle in the presence of polyvinylpyrrolidone and liquid nitrogen, and then stored at $-86^{\circ} \mathrm{C}$.

The $\alpha$-amylase extraction was completed using $0.2 \mathrm{M}$ Tris-HCl, $\mathrm{pH} 8.0$, buffer $+0.1 \%$ mercaptoethanol, using a ratio of $250 \mu \mathrm{L}$ buffer to $100 \mathrm{mg}$ seeds. The material was homogenized in a vortex and stored in a refrigerator for $8 \mathrm{~h}$; it was then centrifuged at 14,000 rpm for $30 \mathrm{~min}$ at $4^{\circ} \mathrm{C}$ and visualized following the method of Alfenas (2006). Of note, seeds subjected to all treatments were embedded for $5 \mathrm{~h}$ before the extraction process.

The isocitrate-lyase extraction was completed using $0.2 \mathrm{M}$ Tris- $\mathrm{HCl}, \mathrm{pH} 8.0$, buffer + $0.1 \%$ mercaptoethanol $+0.1 \%$ phenylhydrazine, at a ratio of $300 \mu \mathrm{L}$ buffer to $100 \mathrm{mg}$ seeds. The material was homogenized in a vortex and stored in a refrigerator for $2 \mathrm{~h}$, after which it was centrifuged at $14,000 \mathrm{rpm}$ for $60 \mathrm{~min}$ at $4^{\circ} \mathrm{C}$. The gels were visualized using the procedures proposed by Pereira (2012).

Electrophoresis was performed using 2 sequential polyacrylamide gels (i.e., 7.5 and $4.5 \%$ separating and stacking gels, respectively). Tris-glycine buffer, $\mathrm{pH} 8.9$, was used in the gel/electrode system. Fifty microliters of supernatant from each sample was applied to the gel, and electrophoresis was run at $120 \mathrm{~V}$ for $5 \mathrm{~h}$.

For the extraction of the enzyme endo- $\beta$-mannanase, microcentrifuge tubes containing $100 \mathrm{mg}$ ground sample were mixed with $300 \mu \mathrm{L}$ extraction buffer [0.1 M HEPES/0.5 M $\mathrm{NaCl}$ and ascorbic acid (5 $\mathrm{mg}$ ascorbic acid per $1 \mathrm{~mL}$ buffer), $\mathrm{pH} 8.0$ ]. Samples were then centrifuged at $14,000 \mathrm{rpm}$ for $30 \mathrm{~min}$, and $2-\mu \mathrm{L}$ aliquot supernatant was applied to gels containing 6-mL locust bean gum, $0.24 \mathrm{~g}$ agarose, and $24 \mathrm{~mL}$ buffer ( $\mathrm{pH} 5.0,1 \mathrm{M}$ citric acid/0.4 $\mathrm{M} \mathrm{Na}_{2} \mathrm{HPO}_{4} 2 \mathrm{H}_{2} \mathrm{O}$ ). The aliquots were placed in 2-mm holes created by a hole puncher. The gel was incubated for $21 \mathrm{~h}$ and visualized using the methodology proposed by da Silva et al. (2004). Endo- $\beta$-mannanase activity was determined as suggested by Downie et al. (1994).

To assess gene expression using PCR, RNA extraction was performed for seeds harvested at different developmental stages. Samples were ground in liquid nitrogen, with the addition of Pure Link RNA Plant ${ }^{\circledR}$ according to manufacturer specifications.

The integrity and purity of the RNA preparation were assessed at all steps via electrophoresis on a denaturing agarose gel (stained with $\mathrm{SYBR}^{\circledR}$ Green II; Applied Biosystems) and spectrophotometer (NanoVue).

Following nucleic acid extraction, the samples were treated with DNAs to avoid DNA 
contamination. This action was performed using the kit DNAse Turbo Free ${ }^{\circledR}$ AMBIOM following the protocol recommended by the manufacturer.

After RNA extraction and purification, the messenger RNAs (mRNAs) were used as templates for the synthesis of complementary DNA (cDNA). The kit High Capacity cDNA Reverse Transcription $\mathrm{cDNA}^{\circledR}$ (Applied Biosystems) was used, following the protocol recommended by the manufacturer. The efficiency of cDNA synthesis was confirmed by means of conventional PCR.

The sequences of the target genes were obtained by searching the GenBank database for red pepper genome sequences. The primers were designed based on the obtained sequences by using Primer Express 3.0 (Applied Biosystems). The primer sequences are displayed in Table 1. Gene coding for ubiquitin and glyceraldehyde 3-phosphate dehydrogenase were used as endogenous controls (Wan et al., 2011).

Table 1. Primers used in the qRT-PCR analysis.

\begin{tabular}{ll}
\hline Gene & Sequence (5'-3') \\
\hline Endo-beta-mannanase (MAN2) & F: AATGCCTGAAAAGAAGCAAAACA \\
Abscisic acid (NCED) & R: TTGGTCGGGATACAGATGGATT \\
Alpha-amylase (B73) & F: TGCAGCCTCCTAGTGCTTGTAC \\
Isocitrate-lyase (ICL6) & R: TGGAAGAGGACCTGGGATTG \\
Gibberellin (GA ${ }_{3}$ ox $)$ & R: TATAGTCCACGCAGAAC \\
Ubiquitin (UBI 3) & F: CATGAAGGAGCCTGCATGA \\
GAPDH & R: TCTGGAAGCCCAACCAACACA \\
& F: GGTGACCTCCTCCACATATATTATCC \\
& R: TGTTGGGTTCGGTTCACCAT \\
\hline
\end{tabular}

$\mathrm{F}=$ Sequence of the forward primer and $\mathrm{R}=$ sequence of the reverse primer.

RT-PCR was performed on an Applied Biosystems 7500 Real-Time PCR System using the reagents contained in the SYBR ${ }^{\circledR}$ Green PCR Master Mix (Applied Biosystems) and cDNA synthesized from the previously extracted RNA. PCR conditions were as follows: 2 min at $50^{\circ} \mathrm{C}, 10 \mathrm{~min}$ at $95^{\circ} \mathrm{C}, 40$ cycles of $15 \mathrm{~s}$ at $95^{\circ} \mathrm{C}$ and $1 \mathrm{~min}$ at $60^{\circ} \mathrm{C}$, and $15 \mathrm{~s}$ at $95^{\circ} \mathrm{C}$. Data were collected and stored using the 7500 Fast Software (version 2.1). Each reaction contained $1.0 \mu \mathrm{L}$ cDNA, $0.2 \mu \mathrm{L}$ of each primer, and 5.0 $\mu \mathrm{L}$ Master Mix SYBR green UDG with ROX (Invitrogen) to produce a total volume of $10 \mu \mathrm{L}$ per sample. Water was used as the negative control, and endogenous controls were included in all analyses. All reactions were performed in triplicate.

The Applied Biosystems 7500 Real-Time PCR System (version 2.0.1) software was used to collect the data. Relative quantitation was determined using the comparative threshold cycle $(\mathrm{Ct})$ method. For each sample, the $\mathrm{Ct}$ values were normalized based on the $\mathrm{Ct}$ values obtained for the endogenous controls. A validation run was performed in advance to determine the amplification efficiency of the target and endogenous genes; similar results nearing $100 \%$ efficiency were obtained. The following dilutions were used to obtain the standard curve and evaluate PCR efficiency: 1:5, 1:25, 1:125, 1:625, and 1:3125. This procedure also allowed for selection of the optimal cDNA dilution (i.e., 1:5) to be used in each reaction. 
Samples obtained from the seeds harvested at 14 DAA were used as calibration samples. To quantify gene expression using real-time PCR, the corresponding mRNA levels obtained from the samples were compared to those obtained from the controls. Once all raw data were obtained, data analysis was performed using the 7500 Software SDS (Version 2.0.1) program. To calculate gene expression levels, the following variables were considered: $\mathrm{C} t$ (exponential increase of the PCR product) for the target-gene and endogenous control:

$$
\begin{array}{rlr}
\Delta \mathrm{C} t & =\mathrm{C} t \text { (sample) }-\mathrm{C} t \text { (endogenous control) } & \text { (Equation 1) } \\
\Delta \Delta \mathrm{C} t & =\Delta \mathrm{C} t(\text { sample })-\Delta \mathrm{C} t(\text { calibration sample) } & \text { (Equation 2) }
\end{array}
$$

Next, the expression level was calculated using the formula:

$$
\mathrm{RQ}=2^{-\Delta \Delta \mathrm{Ct}}
$$

The physiological qualities of the seeds were assessed by the following tests: first germination count (FGC), germination test (GT), germination speed index (GSI), initial stand (IS), emergence (E), and emergence speed index (ESI). A randomized block design with 4 replications was used to obtain the seeds for the physiological quality tests. Data were subjected to ANOVA, and the means were compared using the Scott-Knott means grouping test with a significance level of 5\%. The R 2.14.1 software (2008) was used for all statistical analyses.

\section{RESULTS} rameters.

According to ANOVA results, a significant effect was observed for all evaluated pa(Figure 1).

Moisture content levels were $>50 \%$ for all samples, regardless of developmental stage

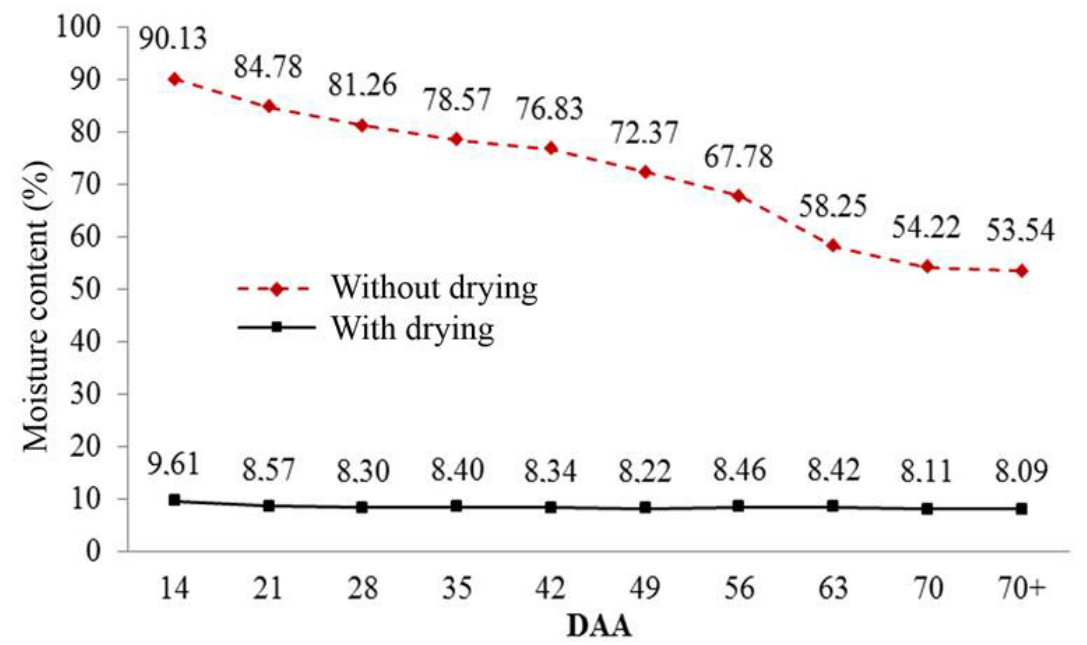

Figure 1. Moisture content of habanero pepper seeds harvested at different developmental stages and after drying. 
The results for FGC, GT, GSI, IS, E, and ESI obtained for wet seeds harvested at different stages after anthesis are displayed in Table 2.

Table 2. Results obtained from the first germination count (FGC), germination test (GT), germination speed index (GSI), initial stand (IS), emergence (E), emergence speed index (ESI), and tetrazolium test (TZ) for habanero pepper seeds that were not subjected to drying and harvested at different developmental stages [i.e., days after anthesis (DAA)].

\begin{tabular}{|c|c|c|c|c|c|c|c|}
\hline DAA & FGC (\%) & GT (\%) & GSI (days) & IS (\%) & E (\%) & ESI (days) & TZ (\%) \\
\hline 14 & $0^{\mathrm{d}}$ & $0^{\mathrm{f}}$ & $0^{\mathrm{f}}$ & $0^{\mathrm{d}}$ & $0^{\mathrm{e}}$ & $0^{\mathrm{d}}$ & - \\
\hline 21 & $0^{\mathrm{d}}$ & $7^{\mathrm{f}}$ & $7^{\circ}$ & $0^{\mathrm{d}}$ & $0^{\mathrm{e}}$ & $0^{\mathrm{d}}$ & - \\
\hline 28 & $3^{\mathrm{d}}$ & $14^{\mathrm{e}}$ & $5^{\mathrm{a}}$ & $2^{\mathrm{d}}$ & $4^{e}$ & $9^{\mathrm{b}}$ & - \\
\hline 35 & $0^{\mathrm{d}}$ & $3^{\mathrm{f}}$ & $6^{\mathrm{b}}$ & $1^{\mathrm{d}}$ & $1^{\mathrm{e}}$ & $9^{\mathrm{b}}$ & - \\
\hline 42 & $0^{\mathrm{d}}$ & $3^{f}$ & $6^{\mathrm{b}}$ & $1^{\mathrm{d}}$ & $2^{\mathrm{e}}$ & $11^{\mathrm{c}}$ & - \\
\hline 49 & $0^{\mathrm{d}}$ & $3^{f}$ & $7^{\mathrm{c}}$ & $12^{\mathrm{c}}$ & $17^{\mathrm{d}}$ & $10^{c}$ & 54 \\
\hline 56 & $1^{\mathrm{d}}$ & $28^{\mathrm{d}}$ & $6^{\mathrm{b}}$ & $13^{\mathrm{c}}$ & $23^{c}$ & $9^{\mathrm{b}}$ & 64 \\
\hline 63 & $17^{\mathrm{c}}$ & $39^{\circ}$ & $6^{\mathrm{b}}$ & $14^{c}$ & $23^{\mathrm{c}}$ & $8^{\mathrm{a}}$ & 68 \\
\hline 70 & $24^{\mathrm{b}}$ & $44^{\mathrm{b}}$ & $6^{\mathrm{b}}$ & $29^{\mathrm{b}}$ & $55^{\mathrm{b}}$ & $8^{\mathrm{a}}$ & 72 \\
\hline $70+$ & $54^{\mathrm{a}}$ & $73^{\mathrm{a}}$ & $5^{\mathrm{a}}$ & $56^{\mathrm{a}}$ & $75^{\mathrm{a}}$ & $8^{\mathrm{a}}$ & 89 \\
\hline CV (\%) & 16.05 & 14.05 & 4.3 & 9.28 & 8.87 & 4.6- & \\
\hline
\end{tabular}

Mean values followed by the same letter in a given column belong to the same group as determined by the ScottKnott test, with 5\% significance.

These data show that the values were generally lower for the seeds harvested during the earlier developmental stages. Higher germination and emergence values were observed in the seeds harvested from fruits at 70 DAA that were subsequently subjected to a 7-day period of rest. The best value for GSI was observed for seeds harvested at 70 DAA with rest, and there was no significant difference among the seeds harvested from the fruits obtained at 56, 63, and 70 DAA. The ESI results showed no significant difference in seed vigor for seeds harvested from 63 DAA.

The results of the FGC, GT, GSI, IS, E, and ESI tests performed on habanero pepper seeds harvested at different developmental stages and subjected to drying are displayed in Table 3.

Table 3. Results obtained from first germination count (FGC), germination test (GT), germination speed index (GSI), initial stand (IS), emergence (E), emergence speed index (ESI), and tetrazolium test (TZ) for dried habanero pepper seeds harvested at different developmental stages [i.e., days after anthesis (DAA)].

\begin{tabular}{|c|c|c|c|c|c|c|c|}
\hline DAA & FGC (\%) & GT (\%) & GSI (days) & IS (\%) & E (\%) & ESI (days) & TZ (\%) \\
\hline 14 & $0^{\mathrm{d}}$ & $0^{\mathrm{f}}$ & $0^{c}$ & $0^{\mathrm{f}}$ & $0^{\mathrm{g}}$ & $0^{b}$ & - \\
\hline 21 & $0^{\mathrm{d}}$ & $4^{\mathrm{c}}$ & $8^{\mathrm{b}}$ & $0^{\mathrm{f}}$ & $5^{\mathrm{f}}$ & $12^{a}$ & - \\
\hline 28 & $0^{\mathrm{d}}$ & $7^{e}$ & $8^{\mathrm{b}}$ & $0^{f}$ & $8^{\mathrm{f}}$ & $11^{\mathrm{a}}$ & - \\
\hline 35 & $0^{\mathrm{d}}$ & $2^{\mathrm{f}}$ & $7^{\mathrm{b}}$ & $5^{\mathrm{e}}$ & $14^{\circ}$ & $13^{\mathrm{a}}$ & - \\
\hline 42 & $0^{\mathrm{d}}$ & $1^{\mathrm{f}}$ & $5^{\mathrm{a}}$ & $1^{\mathrm{f}}$ & $7^{\mathrm{f}}$ & $12^{\mathrm{a}}$ & - \\
\hline 49 & $0^{\mathrm{d}}$ & $2^{\mathrm{f}}$ & $7^{b}$ & $1^{\mathrm{f}}$ & $7^{\mathrm{f}}$ & $13^{\mathrm{a}}$ & 64 \\
\hline 56 & $5^{\mathrm{c}}$ & $33^{d}$ & $7^{b}$ & $13^{\mathrm{d}}$ & $39^{d}$ & $11^{\mathrm{a}}$ & 70 \\
\hline 63 & $28^{\mathrm{b}}$ & $44^{\circ}$ & $5^{\mathrm{a}}$ & $16^{\mathrm{c}}$ & $44^{\circ}$ & $10^{\mathrm{a}}$ & 74 \\
\hline 70 & $26^{\mathrm{b}}$ & $51^{\mathrm{b}}$ & $5^{\mathrm{a}}$ & $33^{\mathrm{d}}$ & $61^{\mathrm{b}}$ & $9^{\mathrm{a}}$ & 72 \\
\hline $70+$ & $73^{a}$ & $94^{a}$ & $4^{a}$ & $58^{\mathrm{a}}$ & $81^{\mathrm{a}}$ & $9^{a}$ & 90 \\
\hline CV (\%) & 18.49 & 9.43 & 37.7 & 12.74 & 6.89 & 37.5 & - \\
\hline
\end{tabular}

Mean values followed by the same letter in a given column belong to the same group as determined by the ScottKnott test, with $5 \%$ significance.

The highest measurements for seed germination and vigor were observed in the seeds harvested from fruits at 70 DAA with rest, except for the ESI test results. There were no statis- 
tically significant differences in the average times to obtain $50 \%$ emergence for the seedlings obtained from the seeds at 63, 70, and 70 DAA with rest.

Electrophoretic analysis of the activity of the enzyme isocitrate-lyase in the seeds harvested at different developmental stages and not subjected to drying (Figure 2A) showed the presence of isoforms from 56 DAA. This enzyme displayed higher activity levels in the seeds during the advanced stages of maturity, with the highest activity levels observed in the seeds harvested at 63 and 70 DAA with rest.

The activity of $\alpha$-amylase (Figure 2B) was observed after 63 DAA in pepper seeds harvested at different developmental stages that were and were not subjected to drying; however, this enzyme exhibited higher activity levels in the seeds that were subjected to drying.
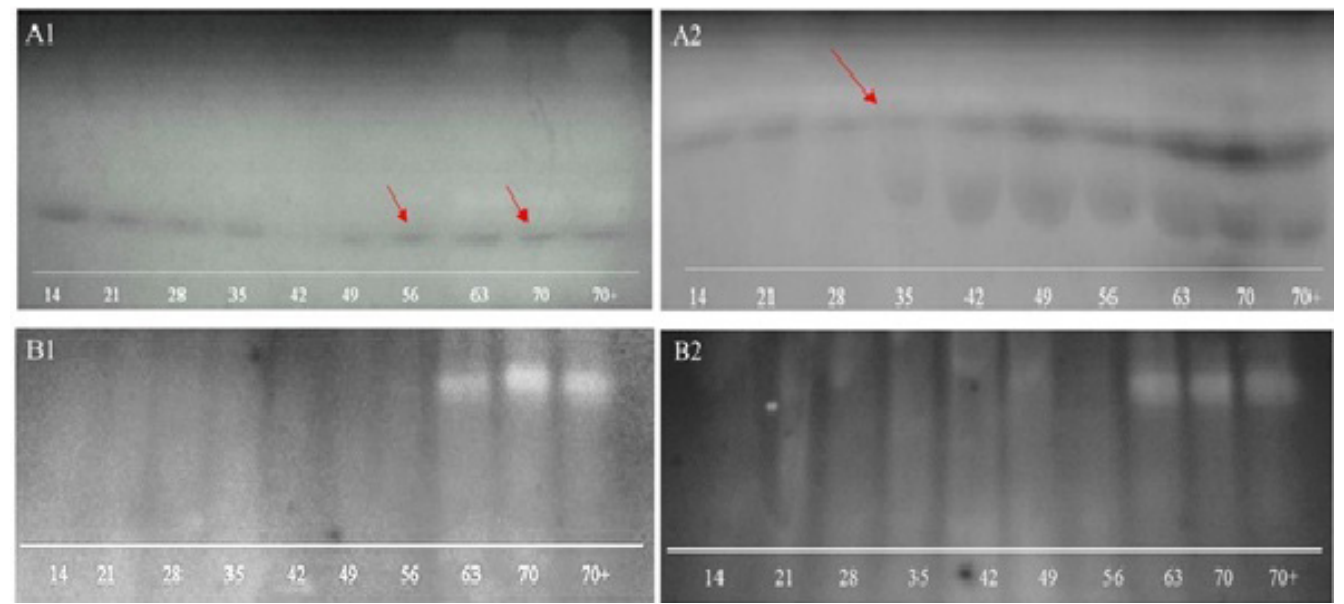

Figure 2. Activity of the enzymes isocitrate-lyase (A) and alpha-amylase (B) in habanero pepper seeds that were not (2) subjected to drying after harvesting at different developmental stages.

Higher activity levels of the enzyme endo- $\beta$-mannanase were observed in the seeds that were harvested at the developmental stage corresponding to 70 DAA with rest, regardless of drying status (Table 4).

Table 4. Activity of the enzyme endo- $\beta$-mannanase in habanero pepper seeds harvested at different developmental stages (picomol. $\mathrm{min}^{-1} \cdot \mathrm{g}^{-1}$ ).

\begin{tabular}{lcc}
\hline DAA & Non-dried seeds & Dried seeds \\
\hline 14 & $21.80^{\mathrm{f}}$ & $9.42^{\mathrm{c}}$ \\
21 & $21.67^{\mathrm{f}}$ & $9.35^{\mathrm{e}}$ \\
28 & $50.36^{\mathrm{d}}$ & $12.60^{\mathrm{d}}$ \\
35 & $21.50^{\mathrm{f}}$ & $9.63^{\mathrm{e}}$ \\
42 & $19.67^{\mathrm{f}}$ & $9.74^{\mathrm{e}}$ \\
49 & $42.30^{\mathrm{e}}$ & $9.79^{\mathrm{e}}$ \\
56 & $51.37^{\mathrm{d}}$ & $12.29^{\mathrm{d}}$ \\
63 & $57.55^{\mathrm{c}}$ & $13.21^{\mathrm{c}}$ \\
70 & $67.55^{\mathrm{b}}$ & $14.35^{\mathrm{b}}$ \\
$70+$ & $76.05^{\mathrm{a}}$ & $16.61^{\mathrm{a}}$ \\
CV $(\%)$ & 3.3 & 2.73 \\
\hline
\end{tabular}

Mean values followed by the same letter in a given column belong to the same group as determined by the ScottKnott test, with 5\% significance. 
The gene expression tests analyzed by real-time PCR indicated that total RNAs extracted using the PureLink Plant RNA reagent were of high quality and integrity, and free of impurities. The cDNAs generated following amplification using the constitutive gene primers were highly viable. Of note, the dissociation curves obtained for each treatment did not show nonspecific bands or primer dimers. In general, the gene expression analysis produced highly variable gene expression levels from the seeds harvested at different developmental stages.

The relative quantification for the ICL6, $\alpha$-amylase gene B73 (AmyB73), and MAN2 genes obtained from habanero pepper seeds harvested at different developmental stages are presented in Figure 3.
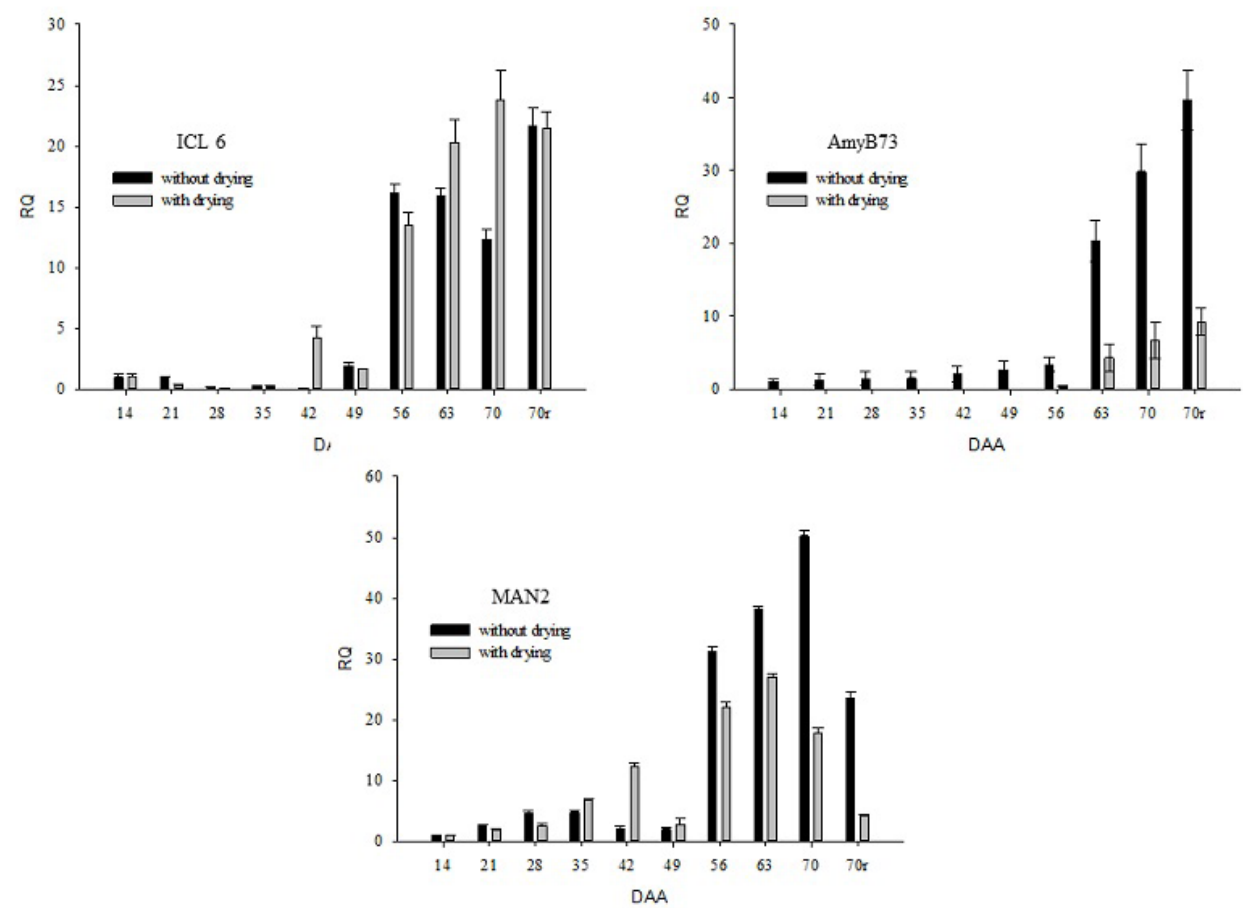

Figure 3. Relative quantification (RQ) profile for the ICL6, $A m y B 73$, and $M A N 2$ genes obtained from habanero pepper seeds harvested at different developmental stages.

There was a gradual increase in the expression level of the ICL6 gene during seed development; $A m y B 73$ expression increased during seed development, particularly after 63 DAA in the seeds that were and were not subjected to drying.

The MAN2 gene was expressed in the developing seeds that were not subjected to drying and harvested up to 70 DAA.

The quantitative analysis of the expression of the NCED gene at different developmental stages is shown in Figure 4. Gene expression increased during seed development, regardless of whether the seeds were dried or not.

The expression of the GA3oxl gene increased in seeds collected during the 5 initial developmental stages; the highest values were recorded for the seeds harvested at 42 DAA (Figure 4). 

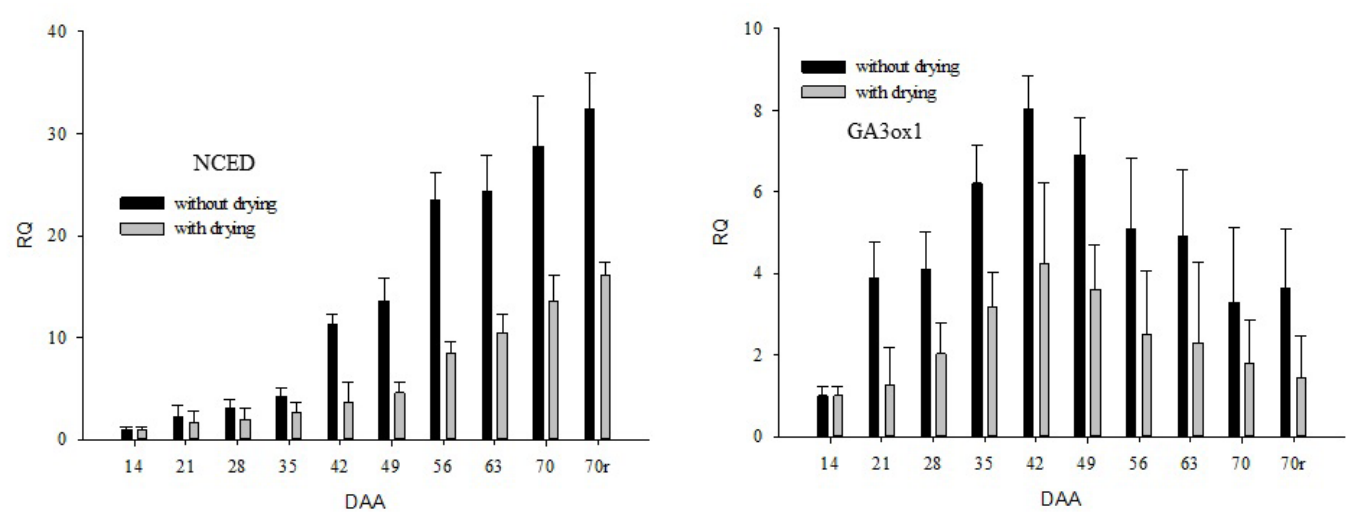

Figure 4. Relative quantification (RQ) profile for the NCED and GA3oxl genes obtained from habanero pepper seeds harvested at different developmental stages (without drying and with drying).

\section{DISCUSSION}

The values for moisture content were high; hence, the samples were dried to avoid deterioration and the generation of products that can cause immediate damage, as described by Caseiro et al. (2004).

In relation to the physiological tests for the seeds that were not subjected to drying, the results were probably influenced by the physiologically premature state associated with seed dormancy. According to Bosland and Votava (1999), and Queiroz et al. (2011), dormancy may occur in non-dried seeds obtained from species of the genus Capsicum.

According to physiological tests for the dried seeds, the results indicated that seed dormancy is disrupted in fruits subjected to rest; thus, the physiological quality of the seeds is favored. Tokuhisa et al. (2008) stated that genotype and fruit age affect the intensity of seed dormancy; seeds harvested from ripened fruits germinate more rapidly, and younger fruits display higher intensities of seed dormancy. According to Nascimento and Freitas (2006), in species where seeds are contained in fleshy fruits, such as peppers, the maximum values for seed germination, vigor, and buildup of dry matter occur when the seeds reach physiological maturity. In seeds harvested at the developmental stages corresponding to $14,21,28,35,42$, and 49 DAA, the germination and emergence values were very low, probably due to seed dormancy.

The enzyme isocitrate-lyase displayed higher activity levels in the seeds during the advanced stages of maturity, with the highest activity levels observed in the seeds harvested at 63 and 70 DAA with rest. Martins et al. (2000) showed that the enzyme isocitrate-lyase exhibited higher activity levels in the soybean seeds from the cultivar Doko, which normally displays better physiological quality with regard to its seeds than that of other cultivars within the same species. These results support those obtained for the pepper in the current study, in which the highest isocitrate-lyase activity levels were measured in the seeds harvested during the more advanced developmental stages, with high germination and vigor values (Tables 3 and 4). The onset of isocitrate-lyase activity was observed at 35 DAA for pepper seeds that were subjected to drying. Enzymatic activity gradually increased during the subsequent developmental stages. These results might be related to the higher germination and vigor values observed for the seeds harvested during the more advanced developmental stages (Table 3). It was also observed that 
drying the seeds to achieve a moisture content of $8 \%$ favors the expression of isocitrate-lyase in the seeds harvested during the less advanced developmental stages. Dried seeds and non-dried seeds displayed isocitrate-lyase activity at 35 and 56 DAA, respectively.

The breakdown of starch, which is the main energy source in most cultivated seeds, is essential for the germination of pepper seeds (Yamasaki, 2003). The substantial increase in $\alpha$-amylase activity from 56 DAA onwards also coincided with higher germination and vigor values (Tables 3 and 4).

It was noted that the seeds harvested at 70 DAA had already reached physiological maturity, exhibiting full development of the enzymatic mechanisms involved in germination. The activity of this enzyme, which is critical for the germination of the pepper seeds, was higher during the more advanced developmental stages.

These results support those presented by Caixeta (2009), who also observed higher activity levels of endo- $\beta$-mannanase during the more advanced developmental stages of the habanero pepper seeds harvested across 3 different developmental stages.

Lower activity levels of this enzyme were observed in the dried seeds harvested at 70 DAA in comparison to the non-dried seeds. It is important to note that there was a considerable difference in the moisture content of these seeds (i.e., 53.54 and $8.09 \%$ for non-dried and dried seeds, respectively). This difference might explain the results, as reported by Pereira (2011), who observed higher activities for endo- $\beta$-mannanase in wet Coffea arabica L. seeds in comparison to those in dried seeds.

Seeds that tolerate desiccation and survive drying for extended periods, depending on the storage conditions, are designated as orthodox seeds. These seeds acquire the ability to germinate and, thus, tolerate desiccation following tissue differentiation prior to maturation drying (Bewley and Black, 1994). However, this tolerance to drying is not uniform throughout the developmental process of the seed. Thus, it cannot be confirmed whether tolerance to desiccation is developed before water loss or as a result of water loss during maturation (Faria et al, 2004).

There was a gradual increase in the expression of the ICL6 gene during seed development, showing a direct correlation with increases in germination and vigor.

With the exception of seeds harvested at 49 DAA and those harvested at 70 DAA with subsequent rest, seeds harvested at 42 DAA and subjected to drying showed higher expression levels of the enzyme isocitrate-lyase (ICL6). These results are comparable to those from the proteomic analysis obtained by electrophoresis, where higher expression levels of the enzyme were found for seeds harvested from 35 DAA and subjected to drying (Figure 2). An isoform of the enzyme appears with these treatments, which was not found in the non-dried seeds. Drying is important in orthodox species that tolerate desiccation, such as pepper seeds, because the drying rate affects the response to dehydration in developing seeds and tolerance to desiccation in plant tissues. Of note, isocitrate-lyase is considered a key enzyme in the regulation of the glyoxylate cycle, and it is also involved in the metabolism of stored lipids and the development of glyoxysomal activity. Insoluble lipids found in seeds are converted into soluble sugars (sucrose) via the glyoxylate cycle; then they are easily transferred to the roots and apical meristems (Zorato et al., 2007).

According to Oliveira (2011), peppers of the genus Capsicum have a chemical composition that is $\sim 11.0 \%$ lipids. However, Topuz and Ozdemir (2007) reported that the chemical composition of peppers is diverse, and the levels of these compounds may vary with genotype, degree of maturation, type of soil, season of the year, and insolation, among other factors (Kokopelli, 2013). 
$A m y B 73$ expression increased during seed development, particularly after 63 DAA in the seeds that were and were not dried. Through electrophoresis, Caixeta (2009) showed that habanero pepper seeds with high physiological qualities exhibited higher $\alpha$-amylase activities. This author also reported that, even though these seeds have low starch contents, $\alpha$-amylase appears to be important in the germination process of this species. Lower gene expression was detected in the dried seeds. This result might be related to the fact that amylases involved in seed germination are synthesized "de novo", which requires that the seeds be soaked in water to germinate. According to Xie et al. (2007), gibberellin (GA) is synthesized in the embryo after soaking, which then activates the synthesis of $\alpha$-amylase. However, previous studies have not investigated whether drying might also work as an inductor of $\alpha$-amylase expression. Oliveira et al. (2013) observed that the $A m y B 73$ gene had higher expression levels in corn seeds that were smaller and subjected to soaking in comparison to the expression levels in those that were bigger and subjected to drying. In the current study, the AmyB73 gene exhibited higher expression levels in the seeds harvested from the fruits obtained at 70 DAA that had not been dried and had been left to rest for 7 days. Of note, these seeds also exhibited higher germination and vigor values (Tables 2 and 3). Both the real-time PCR and electrophoresis results showed an increase in enzyme expression levels with seed development in the $\alpha$-amylase zymogram obtained for the seeds not subjected to drying. Specific isoforms were expressed in the seeds that were subjected to drying and harvested after 63 DAA (Figure 2). This specific isoform might be associated with the $A m y B 73$ gene, since the expression of this gene occurred after 63 DAA in the dried seeds, following a similar pattern to that observed when expression of this enzyme was assessed by electrophoresis.

The MAN2 gene exhibited a similar pattern in germination rate to that observed during the development of the seeds of various species. The germination rate increased early during development; it then declined at 42 and 49 DAA, which was followed by a subsequent increase after 56 DAA. Similar results were observed by Teófilo et al. (1996); they recorded an increase in the germination rate of bean seeds during the early developmental stages, followed by a decrease during the intermediate and an increase during the late developmental stages. Dried and non-dried seeds that were harvested at 70 DAA and rested for 7 days exhibited reduced expression levels for this gene. These seeds expressed the highest values for germination and vigor (Tables 2 and 3 ).

Of importance, seeds that were harvested at 70 DAA without drying and rested for an additional 7 days had a moisture content of $53.54 \%$, which was lower than that of all other seed types at various developmental stages. However, the difference in moisture contents between the seeds harvested at 70 DAA and those harvested at 70 DAA with rest does not appear to explain this finding. The enzyme endo- $\beta$-mannanase is considered essential in the germination process because it is involved in the softening of the endosperm (da Silva et al., 2004). Thus, this softening process arises as a consequence of the activity of this enzyme, which causes hydrolysis of the cell wall. This process has been widely investigated in the seeds from the tomato, coffee, and lettuce plants (Groot and Karssen, 1987; Nonogaki et al., 1992). In contrast, Dahal et al. (1997) found no correlation between $\beta$-mannanase activity and germination in the seeds of the tomato Lycopersicon esculentum (i.e., a correlation between enzyme activity and germination rate was not observed). These authors found that, even though there was an increase in $\beta$-mannanase activity in the seeds before the projection of the rootlet, the reduction in water potential either delayed or prevented the emergence of the rootlet. Dutta et al. (1997) reported that this enzyme is expressed before germination, and it is regulated by 
the same conditions that control germination. Consequently, enzyme activity decreases with increases in seed germination rates.

The NCED gene is associated with the biosynthesis of ABA. The highest expression values for this gene were documented during the late stages of development, which corresponded to the physiological maturation point of seed. The lowest expression values were recorded during the early stages of development (i.e., 14 DAA).

In this study, higher germination and vigor values were recorded in the seeds harvested during the more advanced developmental stages. However, ABA is known to inhibit seed germination. Consequently, the NCED gene had less of an effect on ABA synthesis and, hence, seed germination. Different genes associated with ABA synthesis, including $r d 29 B$, rab18, $A B I 1$, and $A B I 2$, have been reported in the published literature (Kang et al., 2002).

Contreras et al. (2009) found high levels of endogenous ABA in lettuce (Lactuca sativa 'Tango') seeds during the intermediate and late developmental stages, which correspond to the point when seeds become tolerant to desiccation. Clemente et al. (2013) also obtained the same results for lettuce seeds, in which the expression of the $L S N C E D$ gene was higher during the late developmental stages. A similar increase in gene expression was observed in this study for dried seeds harvested during the more advanced developmental stages; however, the relative values were lower. These findings confirm those reported by Finch-Savage and Leubner-Metzger (2006), who proposed that ABA synthesis is directly associated with the moisture content of the seeds, with the lowest values obtained from the seeds with low moisture contents.

After 42 DAA, the absolute expression values for the GA3oxl gene were low for the dried and non-dried seeds. However, there was no significant difference between the gene expression values obtained for the non-dried seeds harvested at 56 and $63 \mathrm{DAA}, 63$ and 70 DAA, and at 70 DAA, with or without rest. Dried seeds exhibited no significant difference in gene expression values between those harvested at 42 and $49 \mathrm{DAA}$, or 49, 56, 63, 70, and $70 \mathrm{DAA}$. In general, lower gene expression values were observed for seeds collected at the end of the development process compared to the maximum expression values observed for the seeds harvested at 42 DAA. This gene was expected to exhibit higher expression levels in the seeds obtained from the fruits harvested at $70 \mathrm{DAA}$, with and without rest, in comparison to germination and vigor tests. Likewise, lower expression values for the gene NCED were expected for the seeds during these developmental stages. However, the expression of these 2 genes was consistent in the seeds harvested during the more advanced developmental stages, with an increase in NCED expression and a decrease in GA3oxl expression. Toh et al. (2008) stated that GA 3-oxidase is involved in the final phase of GA biosynthesis. GA production is necessary for the survival of seeds during embryogenesis (Singh et al., 2002; Sawada et al., 2008). Moreover, the establishment of dormancy during seed maturation is regulated by interactions between GA and ABA, whereby ABA induces dormancy and GA promotes germination (Holdsworth et al., 2008). Singh et al. (2002) reported that GA has a critical role at the onset of seed germination, while $\mathrm{ABA}$ is required during the maturation process. GA levels increase during seed development, in parallel to primary dormancy via activity of the phytohormone ABA.

\section{CONCLUSIONS}

Higher values for seed germination and vigor were obtained in the habanero pepper seeds obtained from the fruits harvested at 70 DAA and subjected to rest for 7 days. Higher expression levels of the $\alpha$-amylase enzyme and the $A m y B 73$ gene were observed in the seeds 
harvested after 63 DAA that were not subjected to drying. Higher activity of the endo- $\beta$ mannanase enzyme was observed in the seeds obtained from the fruits harvested at 70 DAA and subjected to rest for 7 days. MAN2 gene expression in non-dried seeds increased with seed development until 70 DAA. Higher isocitrate-lyase enzyme activity and ICL6 gene expression were observed in the seeds obtained from the fruits harvested at 42 DAA.

\section{ACKNOWLEDGMENTS}

Research supported by Conselho Nacional de Desenvolvimento Científico e Tecnológico $(\mathrm{CNPq})$ and Fundação de Amparo à Pesquisa do Estado de Minas Gerais (FAPEMIG).

\section{REFERENCES}

Alfenas AC (2006). Eletroforese e marcadores bioquímicos em plantas e microrganismos. UFV, Viçosa.

Bewley JD and Black M (1994). Seeds. Physiology of development and germination. 2nd edn. Plenum, New York.

Bosland PW and Votava EJ (1999). Peppers: vegetable and spice Capsicums CAB International, Crop Production Science in Horticulture, Wallingford.

Brasil (2009). Ministério da Agricultura e Reforma Agrária. Coordenação de Laboratório Vegetal. Regras para análise de sementes. MARA, Brasília.

Caixeta F (2009). Modificações fisiológicas e proteínas durante o desenvolvimento, germinação e armazenamento de sementes de pimenta malagueta (Capsicum frutescens L.) e habanero yellow (Capsicum chinense). Master's thesis, Universidade Federal de Lavras, Lavras.

Caseiro RF, Bennett MA and Marcos Filho J (2004). Comparison of three priming techniques for onion seed lots differing in initial seed quality. Seed Sci. Technol. 32: 365-375.

Clemente ACS, Guimaraes RM, Martins DC, Lima AA, et al. (2013). Gene expression associated with the biosynthetic pathway of abscisic acid, gibberellin and ethylene during lettuce seed development. Afr. J. Biotechnol. 12: 3676-3684.

Contreras S, Bennett MA, Metzger JD, Tay D, et al. (2009). Red to far-red ratio during seed development affects lettuce seed germinability and longevity. HortScience 44: 130-134.

da Silva EA, Toorop PE, van Aelst AC and Hilhorst HW (2004). Abscisic acid controls embryo growth potential and endosperm cap weakening during coffee (Coffea arabica cv. Rubi) seed germination. Planta 220: 251-261.

Dahal P, Nevins DJ and Bradford KJ (1997). Relationship of endo-[beta]-D-mannanase activity and cell wall hydrolysis in tomato endosperm to germination rates. Plant Physiol. 113: 1243-1252.

Downie B, Hilhorst HWM and Bewley JD (1994). A new assay for quantifying endo- $\beta$-mannanase activity using Congo Red dye. Phytochemistry 36: 829-835.

Dutta S, Bradford KJ and Nevins DJ (1997). Endo $\beta$ mannanase activity present in cell wall extracts of lettuce endosperm prior to radicle emergence. Plant Physiol. 113: 155-161.

Faria MAVR, Von Pinho RG, Von Pinho EVR, Guimarães RM, et al. (2004). Germinabilidade e tolerância à dessecação em sementes de milho colhida em diferentes estádios de maturação. Rev. Bras. Milho Sorgo 3: 276-289.

Finch-Savage WE and Leubner-Metzger G (2006). Seed dormancy and the control of germination. New Phytol. 171: 501-523.

Groot SPC and Karssen CM (1987). Gibberellins regulate seed germination in tomato by endosperm weakening: a study with gibberellin-deficient mutants. Planta 171: 525-531.

Holdsworth MJ, Bentsink L and Soppe WJ (2008). Molecular networks regulating Arabidopsis seed maturation, afterripening, dormancy and germination. New Phytol. 179: 33-54.

Kang JY, Choi HI, Im MY and Kim SY (2002). Arabidopsis basic leucine zipper proteins that mediate stress-responsive abscisic acid signaling. Plant Cell 14: 343-357.

Kokopelli (2013). Pimentas: história e nutrição. Available at [http://www.kokopelli-seed-foundation.com/]. Accessed January 20, 2013.

Martins CAO, Sediyama CS, Oliveira MDA, José IC, et al. (2000). Atividade da isocitrato-liase durante a germinação de sementes de soja. Rev. Bras. Sementes 22: 42-46.

Nascimento WM and Freitas RA (2006). Produção de sementes de pimentas. In: Cultivo de pimentas (Capsicum spp.) no Brasil (Ribeiro CSC, ed.). Embrapa Hortaliças, Brasília, 30-39.

Nonogaki H, Matsushima H and Morohashi Y (1992). Galactomannan hydrolyzing activity develops during priming in the 
micropylar endosperm tip of tomato seeds. Physiol. Plantarum 85: 167-172.

Oliveira AMC (2011). Caracterização química, avaliação da atividade antioxidante in vitro e atividade antifúngica de pimentas do gênero Capsicum spp. Master's thesis, Universidade Federal do Piaú, Terezina.

Oliveira GEC, Von Pinho RG, Andrade T, Von Pinho EVR, et al. (2013). Physiological quality and amylase enzyme expression in maize seeds. Cienc. Agrotecnol. 37: 40-48.

Pereira DM (2011). Atividade da enzima endo- $\beta$-mananase em diferentes partes de sementes de café, antes e após a germinação. Simpósio de Pesquisa de Cafés do Brasil, Araxá.

Pereira RW (2012). Expressão da enzima isocitrato liase em sementes de pimenta habanero (Capsicum chinense Jacquin) colhidas em diferentes estádios de desenvolvimento. Congresso de Iniciação Científica, UFLA, Lavras.

Queiroz LAF, Von Pinho EVR, Oliveira JA, Ferreira VF, et al. (2011). Época de colheita e secagem na qualidade de sementes de pimenta Habanero Yellow. Rev. Bras. Sementes 33: 472-481.

R Development Core Team (2008). R: A language and environment for statistical computing. R Foundation for Statistical Computing, Vienna. Available at [http://www.R-project.org]. Accessed January 12, 2013.

Randle WM and Honma S (1981). Dormancy in peppers. Sci. Hortic. 14: 19-25.

Sawada Y, Aoki M, Nakaminami K, Mitsuhashi W, et al. (2008). Phytochrome- and gibberellin-mediated regulation of abscisic acid metabolism during germination of photoblastic lettuce seeds. Plant Physiol. 146: 1386-1396.

Singh DP, Jermakow AM and Swain SM (2002). Gibberellins are required for seed development and pollen tube growth in Arabidopsis. Plant Cell 14: 3133-3147.

Teófilo EM, Andrade MJB, Fraga AC and Souza IF (1996). Dessecação química pré-colheita na cultura do feijoeiro (Phaseolus vulgaris L.) efeitos sobre a produção de grãos. Cienc. Agrotecnol. 20: 425-436.

Toh S, Imamura A, Watanabe A, Nakabayashi K, et al. (2008). High temperature-induced abscisic acid biosynthesis and its role in the inhibition of gibberellin action in Arabidopsis seeds. Plant Physiol. 146: 1368-1385.

Tokuhisa D, Dias DCFS, Alvarenga EM, Dias LAS, et al. (2008). Época de colheita dos frutos e ocorrência de dormência em sementes de mamão (Carica papaya L.). Rev. Bras. Sementes 30: 75-80.

Topuz A and Ozdemir F (2007). Assessment of carotenoids and ascorbic acid composition of some selected pepper cultivars (Capsicum annuum L.) grown in Turkey. J. Food Compos. Anal. 20: 596-602.

Wan H, Yuan W, Ruan M, Ye Q, et al. (2011). Identification of reference genes for reverse transcription quantitative realtime PCR normalization in pepper (Capsicum annuum L.). Biochem. Biophys. Res. Commun. 416: 24-30.

Xie Z, Zhang ZL, Hanzlik S, Cook E, et al. (2007). Salicylic acid inhibits gibberellin-induced $\alpha$-amylase expression and seed germination via a pathway involving an abscisic-acid-inducible WRKY gene. Plant Mol. Biol. 64: 293-303.

Yamasaki Y (2003). Amylase in germinating millet seeds. Phytochemistry 64: 935-939.

Zorato MF, Peske ST, Takeda C and França Neto JB (2007). Sementes esverdeadas em soja: testes alternativos para determinar a sua qualidade. Rev. Bras. Sementes 29: 1-10. 